\title{
Response of Soybean Cultivars to Bean pod mottle virus Infection
}

Amy D. Ziems and Loren J. Giesler, Department of Plant Pathology, and George L. Graef, Agronomy and Horticulture Department, University of Nebraska, Lincoln 68583; Margaret G. Redinbaugh, United States Department of Agriculture-Agricultural Research Service, Wooster, OH; and Jean L. Vacha, SueAnn Berry, Laurence V. Madden, and Anne E. Dorrance, Department of Plant Pathology, Ohio State University, Wooster 44691

\begin{abstract}
Ziems, A. D., Giesler, L. J., Graef, G. L., Redinbaugh, M. G., Vacha, J. L., Berry, S. A., Madden, L. V., and Dorrance, A. E. 2007. Response of soybean cultivars to Bean pod mottle virus infection. Plant Dis. 91:719-726.

Bean pod mottle virus (BPMV) has become increasingly common in soybean throughout the north-central region of the United States. Yield loss assessments on southern soybean germplasm have reported reductions ranging from 3 to $52 \%$. Currently, no soybean cultivars have been identified with resistance to BPMV. The objective of this study was to determine the impact of BPMV infection on soybean cultivars representing a broad range of northern soybean germplasm by comparing inoculated and noninoculated soybean plants in paired row studies. In all, 30 and 24 cultivars were evaluated in Nebraska (NE) in which soybean plants were inoculated at the V3 to V4 growth stage. Eleven cultivars from public and breeding lines were inoculated at the VC and R5 to R6 growth stages in Ohio $(\mathrm{OH})$. Disease severity, yield, and percent seed coat mottling were assessed at both locations, whereas protein and oil content also were assessed at NE. Yield and percent seed coat mottling was significantly reduced following inoculation at the $\mathrm{VC}(\mathrm{OH})$ and $\mathrm{V} 3$ to V4 (NE) growth stages. In addition, seed oil and protein composition were impacted in 1 of the 2 years of the study. This study demonstrates that substantial yield losses can occur in soybean due to BPMV infection. In addition, protein and oil may be affected depending on the environment during the production season.
\end{abstract}

Bean pod mottle virus (BPMV) (genus Comovirus, family Comoviridae) first was identified in soybean (Glycine max L. Merr.) in 1951 in Arkansas (28) and has caused agronomic problems since this first finding in Mississippi (22) and North Carolina (28). In the north-central region of the United States, the first report of BPMV was during 1968 in Iowa (23); more recently, the virus has been found in the majority of the states in this region $(4,5,8,17,18,21)$. From 1999 to 2004, increased incidence of BPMV in the northcentral region was associated with increased populations and movement of bean leaf beetles (BLB; Cerotoma trifurcata), the primary virus vector (8).

Corresponding author: L. J. Giesler

E-mail: lgiesler1@unl.edu

Mention of trade names or commercial products in this publication is solely for the purpose of providing specific information and does not imply recommendation or endorsement by the University of Nebraska, Ohio State University, and the United States Department of Agriculture.

Accepted for publication 4 January 2007.

doi:10.1094/PDIS-91-6-0719

This article is in the public domain and not copyrightable. It may be freely reprinted with customary crediting of the source. The American Phytopathological Society, 2007.
BPMV infection was reported to reduce soybean yields of southern cultivars between 3 and $52 \%$ (6), with the most severe reductions occurring when virus infection occurs early in soybean development (14). BPMV produces further financial losses for soybean producers because it causes increased seed coat mottling, which is an irregular pattern or streaking of the hilum associated with BPMV infection $(18,38)$. The effects on yield and seed coat mottling are increased when there is a dual infection of BPMV and Soybean mosaic virus, which causes yield losses $>80 \%$ (26). Other symptoms associated with BPMV infection are mild chlorotic mottling of foliage to severe mosaic, leaf rugosity, terminal necrosis, and death $(6,27,29,36)$. Also, a delay in soybean maturation to cause a symptom known as green stem has been reported $(6,27,29,36)$; however, it has been shown recently that green stem is independent of BPMV infection when random plants were tested for BPMV at growth stage R6 (13).

Current management recommendations for reducing BPMV infection include the application of insecticides to manage BLB populations to reduce the potential for virus movement (15). Host resistance has been explored but, currently, no soybean lines have been identified with resistance to BPMV $(29,31,39)$. Transgenic soybean lines expressing the BPMV coat protein are resistant to BPMV infection $(3,24)$; however, this resistance has not been incorporated into commercial soybean cultivars (8).

The goal of this research was to examine the response of soybean cultivars available in the north-central region of the United States to BPMV infection by evaluating symptom expression and effects on agronomic traits in Nebraska and Ohio. Preliminary results from these studies have been published $(25,40)$.

\section{MATERIALS AND METHODS}

Ohio evaluation of soybean cultivars to early and late infection with BPMV. Seven cultivars and four breeding lines (designated collectively as cultivars; Table 1) were planted in Wooster silt loam soil at the Ohio Agricultural Research and Development Center (OARDC), Snyder Farm, near Wooster in 2001. Ten cultivars were planted in a different field at the same location in 2003. No fertilizer was applied to the field prior to or during the studies. Pre-emergence herbicides in 2001 consisted of alachlor (Microtex, 4.6 liters/ha; Monsanto Company, St. Louis) plus linuron (Lorox DF, $2.2 \mathrm{~kg} / \mathrm{ha}$; Griffin LLC, Valdosta, GA) and surfactant (2.3 liters/ha) on the day of planting. The post-emergence herbicide bentazon and acifluorfen (Storm; United Phosphorus Inc., Trenton, NJ) was applied (1.7 liters/ha) on 2 July 2003. The insecticide permethrin (Pounce, $559 \mathrm{~g}$ [a.i.]/ha; FMC Corporation Ag Products, Philadelphia) was applied on 16 July and 15 August to limit the amount of insect leaf feeding during 2001. Lambdacyhalothrin (Warrior, $209 \mathrm{~g}$ [a.i.]/ha; Syngenta Crop Protection, Greensboro, NC) was applied on 2, 16, and 24 July and 21 August 2003. Four $7.62-\mathrm{m}$ rows $(38.1 \mathrm{~cm}$ apart) were planted in a no-till field in a split plot design on 14 June 2001 and 6 June 2003, with soybean cultivar as a whole plot in addition to inoculation time at the unifoliate stage (VC) or R6 to R7. BPMV-inoculated and noninoculated treatments were the subplots.

The Ohio isolate of BPMV was obtained from soybean leaves and maintained in 'Harosoy' seedlings (4). Sequence of reverse-transcription polymerase chain reaction products amplified from RNA1 (615 bp) and RNA2 (789 bp) indicate that both RNAs have $>98 \%$ identity with subgroup II viruses (10; G. L. Redinbaugh and M. G. Redinbaugh, unpublished results). The 
unifoliate leaf was inoculated with a leafrub inoculation at the unifoliate stage (VC) on 28 June 2001 and 24 June 2003. For late-inoculated plots, the youngest fully expanded leaf was inoculated at the R6 to R7 stage on 6 September 2001 and 16 September 2003 as described by Louie et al. (19).

To determine inoculation efficiency, 10 leaf samples were collected randomly from each plot on 21 September 2001 and 23 September 2003 (VC inoculation) and 26 September 2001 and 29 September 2003 (R6 to R7 inoculation) and tested using an $\mathrm{F}(\mathrm{ab})_{2}$ enzyme-linked immunosorbent assay (ELISA) similar to that described by Louie et al. (19) using BPMV antiserum developed at OARDC (D. T. Gordon, unpublished results). Samples were considered positive for BPMV if the mean absorbance at $405 \mathrm{~nm}$ for two replicates was greater than three times the mean absorbance of the healthy controls and greater than the mean value of the healthy controls plus three times the standard deviation of the controls (33).

Visual assessment of plots for BPMV symptoms, including chlorosis and rugosity, was done approximately 4 weeks post inoculation (30 July 2001 and 24 July 2003) or at the R6 to R7 growth stage (5 September 2001 and 25 September 2003) using a visual scale of 1 to 5 , where $1=$ no symptoms, $2=$ some chlorosis present, $3=$ chlorosis evident on all leaves in upper canopy, $4=$ severe chlorosis with some rugosity, and $5=$ severe chlorosis and rugosity on the uppermost set of leaves. During 2001, average plant height was determined by measuring 10 plants in each plot on 30 July. Yield was determined for all plots after mechanical harvest of the two rows on 5 November 2001 and 21 October 2003. In 2001, 100-seed weights were determined following harvest. In
Table 2. Effect of V3 to V4 growth stage inoculation with Bean pod mottle virus (BPMV) on chlorosis and rugosity expression in soybean cultivars evaluated in Nebraska in $2003^{\mathrm{a}}$

\begin{tabular}{|c|c|c|c|c|c|c|}
\hline \multirow[b]{2}{*}{ Cultivar } & \multicolumn{2}{|c|}{ Chlorosis $^{\text {b }}$} & \multicolumn{4}{|c|}{ Rugosity $^{\mathrm{c}}$} \\
\hline & $\mathbf{I}$ & $\mathbf{N}$ & I Med & N Med & I Rel & N Rel \\
\hline Stine S3632-4 & 1.8 & 1.0 & 1.8 & 1.0 & 0.65 & 0.29 \\
\hline Stine S3183-4 & 2.5 & 1.0 & 1.8 & 1.0 & 0.65 & 0.29 \\
\hline Stine S3300-4 & 1.5 & 1.0 & 1.5 & 1.0 & 0.53 & 0.29 \\
\hline NK/Syngenta S28-W2 & 2.3 & 1.0 & 1.8 & 1.0 & 0.65 & 0.29 \\
\hline NK/Syngenta S37-N4 & 3.0 & 1.0 & 2.3 & 1.3 & 0.82 & 0.41 \\
\hline NK/Syngenta S32-G5 & 2.8 & 1.0 & 1.5 & 1.0 & 0.53 & 0.29 \\
\hline Mycogen 5B283RR & 3.3 & 1.0 & 2.3 & 1.0 & 0.82 & 0.29 \\
\hline Mycogen 5B288RR & 1.3 & 1.0 & 1.8 & 1.0 & 0.65 & 0.29 \\
\hline Mycogen 5B311RR & 2.5 & 1.0 & 2.0 & 1.0 & 0.77 & 0.29 \\
\hline Latham 917RR & 3.5 & 1.0 & 2.3 & 1.0 & 0.82 & 0.29 \\
\hline Latham 967RR & 2.5 & 1.0 & 1.8 & 1.0 & 0.65 & 0.29 \\
\hline Latham 1067RR & 1.8 & 1.0 & 1.8 & 1.0 & 0.65 & 0.29 \\
\hline LG Seeds C2625RR & 1.8 & 1.0 & 1.5 & 1.0 & 0.52 & 0.29 \\
\hline LG Seeds C2991RR & 3.3 & 1.0 & 2.0 & 1.0 & 0.77 & 0.29 \\
\hline LG Seeds C3110NRR & 3.0 & 1.0 & 2.0 & 1.0 & 0.77 & 0.29 \\
\hline Garst 2603RR & 2.0 & 1.0 & 2.0 & 1.0 & 0.77 & 0.29 \\
\hline Garst 2802RR & 3.0 & 1.3 & 2.0 & 1.3 & 0.77 & 0.41 \\
\hline Garst 3135RR & 2.0 & 1.0 & 1.5 & 1.0 & 0.53 & 0.29 \\
\hline Kaup 299R & 2.3 & 1.0 & 2.3 & 1.0 & 0.82 & 0.29 \\
\hline Kaup 279R & 2.3 & 1.0 & 2.0 & 1.0 & 0.77 & 0.29 \\
\hline Kaup 267R & 2.0 & 1.0 & 1.8 & 1.0 & 0.65 & 0.29 \\
\hline Croplan RC3335 & 3.0 & 1.0 & 2.3 & 1.3 & 0.82 & 0.41 \\
\hline Croplan RC3212 & 3.5 & 1.0 & 2.0 & 1.0 & 0.77 & 0.29 \\
\hline Croplan RT3176 & 2.0 & 1.0 & 2.0 & 1.0 & 0.77 & 0.29 \\
\hline AgriPro 2677RR & 2.0 & 1.0 & 1.8 & 1.0 & 0.65 & 0.29 \\
\hline AgriPro 2903RR & 5.0 & 1.0 & 3.0 & 1.0 & 0.98 & 0.29 \\
\hline AgriPro 3135RR & 2.0 & 1.0 & 1.5 & 1.0 & 0.53 & 0.29 \\
\hline Asgrow 3003 & 3.0 & 1.0 & 2.0 & 1.0 & 0.65 & 0.29 \\
\hline Asgrow 3302 & 2.5 & 1.0 & 2.0 & 1.0 & 0.77 & 0.29 \\
\hline Dekalb 35-51 & 3.5 & 1.0 & 2.0 & 1.0 & 0.77 & 0.29 \\
\hline
\end{tabular}

a $\mathrm{I}=\mathrm{BPMV}$-inoculated subplots and $\mathrm{N}=$ noninoculated subplots.

${ }^{\mathrm{b}}$ Rating based on a 0 -to- 10 scale, where $0=0 \%$ area leaf chlorotic and $10=100 \%$ leaf area chlorotic. Treatments were compared using Fisher's protected least significant difference (LSD; $P \leq 0.05$ ); inoculation-cultivar $\operatorname{LSD}(\alpha=0.05)=0.9$.

${ }^{\mathrm{c}}$ Rating based on a 1 -to- 5 scale, where $1=$ flat leaves and $5=$ severely crinkled leaves. Med $=$ median and $\mathrm{Rel}=$ relative effect, the probability that the rating of a plant from a given cultivar is greater than the rating of a randomly chosen plant from a population of all cultivars combined. Differences of relative treatment effects loosely represent the magnitude of the difference of the distribution of two cultivars (not just the central value). Treatments were compared using Fisher's protected LSD $(P \leq$ $0.05)$ calculated based on the standard errors for relative treatment effects for each cultivar; inoculation-cultivar LSD $(\alpha=0.05)=0.63$. With the nonparametric analysis, there is a different standard error for every relative treatment effect; thus, this LSD is actually a mean LSD for all possible pairs of cultivars.

Table 1. Effect of VC growth stage inoculation with Bean pod mottle virus on symptom expression of soybean cultivars in Ohio ${ }^{\mathrm{a}}$

\begin{tabular}{|c|c|c|c|c|c|c|c|}
\hline \multirow[b]{2}{*}{ Cultivar } & \multirow[b]{2}{*}{ Type $^{\mathbf{b}}$} & \multicolumn{3}{|c|}{2001} & \multicolumn{3}{|c|}{2003} \\
\hline & & Med July & Med Sept & Rel July & Rel Sept & Med Sept & Rel Sept \\
\hline Defiance & Grain & 3.0 & 3.5 & 0.40 & 0.67 & 2.0 & 0.83 \\
\hline Flint & Grain & 2.5 & 4.0 & 0.34 & 0.77 & $\mathrm{Nt}$ & $\mathrm{Nt}$ \\
\hline General & Grain & 2.0 & 3.5 & 0.16 & 0.67 & 1.0 & 0.48 \\
\hline НC94-24 & IR & 2.2 & 4.0 & 0.29 & 0.74 & 2.0 & 0.71 \\
\hline HC95-15 & IR & 3.0 & 4.0 & 0.47 & 0.81 & 1.5 & 0.59 \\
\hline HF98-023 & Breeding & 2.5 & 4.5 & 0.24 & 0.89 & 1.0 & 0.36 \\
\hline HS93-4118 & Breeding & 1.5 & 3.2 & 0.10 & 0.68 & 1.0 & 0.48 \\
\hline Resnik & Grain & 2.0 & 3.0 & 0.17 & 0.64 & 1.0 & 0.28 \\
\hline Stalwart & Determinant & 2.5 & 3.5 & 0.32 & 0.65 & 1.0 & 0.39 \\
\hline Tiffin & Grain & 3.0 & 3.0 & 0.47 & 0.51 & 1.0 & 0.48 \\
\hline Williams82 & Grain & 2.2 & 4.0 & 0.23 & 0.78 & $\mathrm{Nt}$ & $\mathrm{Nt}$ \\
\hline $\operatorname{LSD}(\alpha=0.05)^{\mathrm{c}}$ & $\ldots$ & $\ldots$ & $\ldots$ & 0.22 & 0.22 & $\ldots$ & 0.28 \\
\hline
\end{tabular}

a Med = median severity and Rel = relative effect in July or September (Sept); Nt = not tested, due to very poor and uneven stands. Symptom severity was determined using a visual scale of 1 to 5 , where $1=$ no symptoms and $5=$ severe mottling and leaf crinkling on the uppermost set of leaves. Relative effect is the probability that the rating of a plant from a given cultivar was greater than the rating of a randomly chosen plant from a population of all cultivars combined. Differences of relative treatment effects loosely represent the magnitude of the difference of the distribution of two cultivars (not just the central value).

b Ohio soybean cultivars and breeding lines were indeterminant grain type and semideterminant insect-resistant (IR) breeding lines.

c Treatments were compared using Fishers protected least significant difference (LSD; $P \leq 0.05$ ), calculated based on the standard errors for relative treatment effects for each cultivar. With the nonparametric analysis, there is a different standard error for every relative treatment effect; thus, the LSD shown is actually a mean LSD for all possible pairs of cultivars. 
addition, 100-seed subsamples from each plot were counted for the number of seed exhibiting seed coat mottling. This value was converted to percent mottled seed.

Nebraska evaluation of soybean cultivars to early infection with BPMV. In all, 30 (Table 2) and 23 (Table 3) Roundup Ready soybean cultivars representing the top market shares from 10 seed companies in Nebraska were planted in Kennebec silt loam soil at the University of NebraskaLincoln East Campus Research Farm in Lincoln during 2003 and 2004, respectively. No fertilizer or herbicide was applied to the field prior to or during the studies. Weed control was managed through rouging. Warrior (209 g [a.i.]/ha) was applied on 13 and 29 July 2003 and 19 July and 17 August 2004 to suppress BLB populations. Plots consisted of three $0.8-\mathrm{m}$ rows on $76-\mathrm{cm}$ spacing. Plots were planted in a field that was disked prior to planting in a split-plot design on 25 May 2003 and 19 May 2004, with soybean cultivar as the whole plots and BPMV-inoculated or noninoculated plants as the subplots. Whole plots were thinned to a common plant population of 6 to 23 plants per $0.76 \mathrm{~m}$ among whole plots at growth stage VC to V1 on 10 June 2003 and 3 June 2004.

A BPMV isolate (subgroup I; identified by S. Ghabrial, personal communication) originally collected from infected soybean in Nebraska was used as the inoculum source. The BPMV isolate was maintained in infected plant material stored at $-20^{\circ} \mathrm{C}$ and by serial transfer using mechanical inoculation to Phaseolus vulgaris $\mathrm{L}$. cv. Landreth. The BPMV inoculum was prepared from symptomatic $P$. vulgaris by blending infected plant tissue in $0.025 \mathrm{M}$ potassium phosphate buffer, $\mathrm{pH} 7.2$ (tissue at $0.1 \mathrm{~g} / \mathrm{ml}$ ). The extract was filtered through cotton flour sack towels to remove insoluble plant material, and $28 \mathrm{~g}$ of Carborundum (Fisher Scientific, 320 grit) was added per liter. Plants were inoculated with the extract using an airbrush (Model 155 \& 175; Badger Air-Brush Co., Franklin Park, IL) at 75 psi. Four leaflets per plant were sprayed until a water-soaked spot was apparent on the leaf surface. Inoculation occurred at growth stage V3 to V4 on 2 and 3 July 2003 and 7 and 8 July 2004.

To determine inoculation efficiency, four and five new, fully expanded trifoliolate leaf samples were collected from each plot on 18 August 2003 and 4 August 2004, respectively, at growth stage R5 to R6. Leaf samples were placed into dry 7.6-by7.6- $\mathrm{cm}$ mesh bags (Agdia, Inc.), and $4 \mathrm{ml}$ of phosphate-buffered saline with Tween (PBST, pH 7.2) was added to each bag and ground using a tissue homogenizer (Agdia,
Inc.). Samples were tested using a biotinavidin double-antibody sandwich ELISA according to Krell et al. (15) using antibodies provided by Dr. John Hill (Iowa State University). Absorbance values (405 $\mathrm{nm}$ ) were determined using an OPTImax Tunable Microplate Reader (Molecular Devices Corporation, Sunnyvale, CA) and were considered positive if the absorbance exceeded twice the mean plus $10 \%$ of the healthy control (extract from noninoculated soybean leaves; 9).

Symptom severity was assessed at growth stage R5 on 17 August 2003 and 10 August 2004 using a visual scale to estimate leaf chlorosis ( 0 to 10 ) and leaf rugosity ( 1 to 5 ) as described by Windham and Ross (37). The chlorosis scale used did include any chlorosis associated with a mosaic pattern typical of plant virus symptoms. Single-row plots were harvested mechanically on 17 October 2003 and 22 October 2004. Following harvest, seed samples were assessed for moisture content, percent oil, and percent protein content with near-infrared spectroscopy (Infratec 1255 Food and Feed Analyzer; Foss, Eden Prairie, MN). All yields, percent oil, and percent protein values were standardized to $13 \%$ moisture. To determine impact of seed coat mottling, 100-seed subsamples from each plot were counted for the

Table 3. Effects of inoculation with Bean pod mottle virus (BPMV) at growth stage V3 to V4 on yield, percent mottled seed, percent oil content, and percent protein content of soybean cultivars evaluated in Nebraska in $2003^{\mathrm{a}}$

\begin{tabular}{|c|c|c|c|c|c|c|c|c|c|c|c|c|}
\hline \multirow[b]{2}{*}{ Cultivar } & \multicolumn{3}{|c|}{ Yield (g/plot) } & \multicolumn{3}{|c|}{ Mottled seed $(\%)^{b}$} & \multicolumn{3}{|c|}{ Oil content (\%) } & \multicolumn{3}{|c|}{ Protein content $(\%)$} \\
\hline & I & $\mathbf{N}$ & Mean & $\mathbf{I}$ & $\mathbf{N}$ & Mean & I & $\mathbf{N}$ & Mean & $\mathbf{I}$ & $\mathbf{N}$ & Mean \\
\hline Stine S3632-4 & 293.6 & 458.8 & 376.2 & 72 & 60 & 66 & 25.1 & 25.7 & 25.4 & 48.6 & 47.4 & 48 \\
\hline Stine S3183-4 & 370 & 430.3 & 400.15 & 63.8 & 61 & 62.4 & 25.3 & 26 & 25.65 & 47.7 & 46.7 & 47.2 \\
\hline Stine S3300-4 & 104.6 & 409.6 & 257.1 & 80 & 85.8 & 82.9 & 24.3 & 24.8 & 24.55 & 49.1 & 48.3 & 48.7 \\
\hline NK/Syngenta S28-W2 & 431.9 & 470.1 & 451 & 85 & 86.3 & 85.65 & 24.7 & 25.5 & 25.1 & 49.4 & 46.4 & 47.9 \\
\hline NK/Syngenta S37-N4 & 346.9 & 288.9 & 317.9 & 71.8 & 74.8 & 73.3 & 24.1 & 24.6 & 24.35 & 49.6 & 47.9 & 48.75 \\
\hline NK/Syngenta S32-G5 & 354.1 & 411.4 & 382.75 & 72 & 49.8 & 60.9 & 24.7 & 25.1 & 24.9 & 47.4 & 49.9 & 48.65 \\
\hline Mycogen 5B283RR & 388.7 & 421 & 404.85 & 86.8 & 83.3 & 85.05 & 24.8 & 24.9 & 24.85 & 48.3 & 47.2 & 47.75 \\
\hline Mycogen 5B288RR & 399.1 & 463 & 431.05 & 80 & 66 & 73 & 24.3 & 24.5 & 24.4 & 50 & 48.2 & 49.1 \\
\hline Mycogen 5B311RR & 339.8 & 422.8 & 381.3 & 66 & 61.5 & 63.75 & 25 & 25.5 & 25.25 & 47.6 & 46.6 & 47.1 \\
\hline Latham 917RR & 359.7 & 402.5 & 381.1 & 85 & 88 & 86.5 & 24.5 & 24.9 & 24.7 & 49.4 & 47 & 48.2 \\
\hline Latham 967RR & 325.5 & 415.3 & 370.4 & 78.3 & 66.8 & 72.55 & 24.6 & 24.6 & 24.6 & 49.2 & 49.1 & 49.15 \\
\hline Latham 1067RR & 422 & 481.4 & 451.7 & 60.8 & 54.6 & 57.7 & 24.2 & 26 & 25.1 & 48.9 & 46.6 & 47.75 \\
\hline LG Seeds C2625RR & 334.3 & 336.3 & 335.3 & 82 & 60.3 & 71.15 & 24.1 & 24 & 24.05 & 49.9 & 50 & 49.95 \\
\hline LG Seeds C2991RR & 339.9 & 434.8 & 387.35 & 77.3 & 69 & 73.15 & 24.7 & 24.9 & 24.8 & 49.1 & 49 & 49.05 \\
\hline LG Seeds C3110NRR & 382.8 & 450.5 & 416.65 & 65.3 & 55.3 & 60.3 & 25 & 26.2 & 25.6 & 49.8 & 48.9 & 49.35 \\
\hline Garst 2603RR & 380.4 & 451.2 & 415.8 & 92.5 & 79.5 & 86 & 24.8 & 25.1 & 24.95 & 50.2 & 49.3 & 49.75 \\
\hline Garst 2802RR & 389.3 & 487.5 & 438.4 & 46.5 & 42 & 44.25 & 25.4 & 25.5 & 25.45 & 48.6 & 48.9 & 48.75 \\
\hline Garst 3135RR & 388.6 & 460.4 & 424.5 & 57 & 52 & 54.5 & 25.2 & 25.7 & 25.45 & 47.5 & 46.5 & 47 \\
\hline Kaup 299R & 377.5 & 441 & 409.25 & 75.5 & 65.8 & 70.65 & 25 & 25.5 & 25.25 & 48.9 & 48.6 & 48.75 \\
\hline Kaup 279R & 428.2 & 430.5 & 429.35 & 89.3 & 75.8 & 82.55 & 24 & 25 & 24.5 & 51.4 & 49.9 & 50.65 \\
\hline Kaup 267R & 348.3 & 365.1 & 356.7 & 87.3 & 88.8 & 88.05 & 24.8 & 25 & 24.9 & 49.6 & 48 & 48.8 \\
\hline Croplan RC3335 & 314.9 & 325.6 & 320.25 & 80.5 & 79 & 79.75 & 24.6 & 25.1 & 24.85 & 48.8 & 47.7 & 48.25 \\
\hline Croplan RC3212 & 380.6 & 450.6 & 415.6 & 45.8 & 37.5 & 41.65 & 24 & 24.9 & 24.45 & 49.2 & 47.4 & 48.3 \\
\hline Croplan RT3176 & 432.5 & 456 & 444.25 & 66.8 & 54.3 & 60.55 & 25 & 24.7 & 24.85 & 48 & 46.4 & 47.2 \\
\hline AgriPro $2677 R R$ & 362.7 & 427.8 & 395.25 & 85 & 72.3 & 78.65 & 25.1 & 25.4 & 25.25 & 48.4 & 47.9 & 48.15 \\
\hline AgriPro 2903RR & 362.4 & 383 & 372.7 & 87.8 & 77.5 & 82.65 & 24.5 & 24.6 & 24.55 & 49.7 & 49 & 49.35 \\
\hline AgriPro $3135 R R$ & 370.5 & 404.3 & 387.4 & 63.5 & 49.5 & 56.5 & 25.1 & 25.7 & 25.4 & 48.3 & 46.9 & 47.6 \\
\hline Asgrow 3003 & 395.8 & 476.5 & 436.15 & 80.2 & 74.5 & 77.35 & 23.8 & 24.8 & 24.3 & 50.5 & 48.8 & 49.65 \\
\hline Asgrow 3302 & 376.6 & 450.2 & 413.4 & 49.8 & 46.8 & 48.3 & 24.2 & 24.6 & 24.4 & 50.6 & 49.4 & 50 \\
\hline Dekalb 35-51 & 398.8 & 439.1 & 418.95 & 78.3 & 78.5 & 78.4 & 23.6 & 23.7 & 23.65 & 50.7 & 49.5 & 50.1 \\
\hline Cultivar LSD ${ }^{\mathrm{c}}$ & 78 & 97.9 & 43.9 & 11 & 12.1 & 5.8 & 0.9 & 0.8 & 0.4 & 1.3 & 1 & 0.6 \\
\hline
\end{tabular}

a $\mathrm{I}=\mathrm{BPMV}$-inoculated subplots and $\mathrm{N}=$ noninoculated subplots.

${ }^{b}$ For percent mottling, a 100-seed subsample from each plot was counted for the number of seed exhibiting seed coat mottling, and this value was converted to percent mottled seed.

${ }^{\mathrm{c}}$ LSD $=$ least significant difference $(\alpha=0.05)$. 
number of seed exhibiting seed coat mottling, and this value was converted to percent mottled seed. The 100 -seed subsample also was assessed for overall seed quality on a 1-to-5 scale with $1=0 \%$ seed area mottled and $5=76$ to $100 \%$ seed area mottled (41).

Statistical analysis. A nonparametric marginal-effects analysis $(1,30)$ was used to determine the effects of cultivar on the ordinal foliar symptom severity ratings in Ohio and rugosity ratings in Nebraska. Assessment time also was analyzed in Ohio for 2001 data. The so-called relative treatment effect (a scaled version of the mean rank of severity; 1,30) was calculated as the summary statistic for comparing among cultivars. The relative treatment effect is the probability that the rating of a plant from a given cultivar is greater than the rating of a randomly chosen plant from a population of all cultivars combined. Differences of relative treatment effects loosely represent the magnitude of the difference of the distribution of two cultivars (not just the central value).

Analysis of variance (ANOVA) was used for the analysis of disease incidence and plant height for plants inoculated at growth stage VC in Ohio. Proc GLM of
SAS (SAS Institute, Cary NC) was used for the ANOVA. ANOVA also was used to test the effects of cultivar and inoculation at each inoculation time (early and late) on chlorosis rating, percent mottled seed, yield, percent oil, and percent protein content. In the analysis of yield in $\mathrm{Ne}$ braska, whole-plot plant population served as a covariant variable. The chlorosis rating, percent mottled seed, yield, percent oil, and percent protein content in the noninoculated and inoculated subplots were analyzed using inoculation and cultivar as main effects. All treatments were compared by Fisher's protected least significant difference $(P<0.05)$. Correlations between the percent mottled seed, yield, percent oil, and percent protein content were calculated using a pointserial correlation coefficient as described by Gibbons (7).

\section{RESULTS}

Efficiency of virus inoculations. In Ohio, $97 \%$ of the soybean plots inoculated at the VC growth stage were all positive for BPMV, except one plot of cv. Stalwart in 2001 and one of cv. General in 2003, whereas $52 \%$ of plots which were inoculated at the R6 to R7 growth stage tested positive for BPMV by ELISA in each year. In Nebraska, the inoculation efficiency for BPMV was $96 \%$ in 2003. In 2004, inoculation efficiency decreased, with $44 \%$ of the leaf material sampled testing positive for BPMV.

Some plants collected from noninoculated plots in both studies tested positive for BPMV. Even when foliar symptoms were not present in any of the noninoculated plots, BPMV was detected in 50 and $14 \%$ of noninoculated plots at the $\mathrm{VC}$ and R6 to R7 stages, respectively, during 2001 In 2003, BPMV was detected in 82 and $2.5 \%$ of the noninoculated plots, in Ohio. For Nebraska, 70 and $29 \%$ of the noninoculated leaf material tested positive for BPMV at growth stage R5 to R6 in 2003 and 2004, respectively.

Symptom severity. In the Ohio study, where BPMV subgroup II was inoculated, symptom severity was significantly lower in plants rated early in the season in 2001, and the interaction between rating date and cultivars was significant $(P<0.05)$, based on the nonparametric marginal-effects analysis (30; Table 1). In general, the estimated relative treatment effects were lower for July than for September, and the corresponding median severity ratings (not di-

Table 4. Analysis of variance for soybean cultivars inoculated with Bean pod mottle virus at the unifoliate and R6 to R7 growth stages in Ohio and for soybean inoculated at V3 to V4 growth stage in Nebraska

\begin{tabular}{|c|c|c|c|c|c|}
\hline \multirow[b]{2}{*}{ Location, year, source } & \multirow[b]{2}{*}{ df } & \multicolumn{4}{|c|}{ Means squares $^{\mathbf{a}}$} \\
\hline & & Yield & Percent mottled seed & Percent oil content & Percent protein content \\
\hline \multicolumn{6}{|l|}{ Ohio $^{\mathrm{b}}$} \\
\hline \multicolumn{6}{|l|}{2001} \\
\hline Replication (Rep) & 3 & $0.1241 *$ & $946.77 *$ & - & - \\
\hline Cultivar (C) & 10 & $0.1996^{*}$ & $2,335.81 * * *$ & - & - \\
\hline $\mathrm{C} \times \operatorname{Rep}$ & 30 & 0.0942 & 465.69 & - & - \\
\hline Inoculation (I) & 1 & $1.4005 * * *$ & $9,077.82 * * *$ & - & - \\
\hline $\mathrm{C} \times \mathrm{I}$ & 10 & 0.03433 & 415.61 & - & - \\
\hline Growth stage (G) & 1 & $1.4292 * * *$ & $15,319.11 * * *$ & - & - \\
\hline $\mathrm{C} \times \mathrm{G}$ & 10 & 0.1077 & 482.30 & - & - \\
\hline $\mathrm{C}(\mathrm{rep} \mathrm{G})$ & 33 & 0.0733 & 570.94 & - & - \\
\hline $\mathrm{C} \times \mathrm{I} \times \mathrm{G}$ & 11 & $0.2708 * * *$ & $1,099.22 * * *$ & - & - \\
\hline \multicolumn{6}{|l|}{2003} \\
\hline Rep & 3 & $0.2400 * * *$ & $161.62 *$ & - & - \\
\hline $\mathrm{C}$ & 8 & $2.0220 * * *$ & $574.94 * * *$ & - & - \\
\hline $\mathrm{C} \times \mathrm{Rep}$ & 27 & 0.0677 & 47.81 & - & - \\
\hline I & 1 & $4.6333 * * *$ & $1,374.76 * * *$ & - & - \\
\hline $\mathrm{C} \times \mathrm{I}$ & 8 & 0.0280 & 74.94 & - & - \\
\hline G & 1 & $1.8413 * * *$ & $3,468.91 * * *$ & - & - \\
\hline $\mathrm{C} \times \mathrm{G}$ & 9 & 0.0202 & $232.03 * * *$ & - & - \\
\hline $\mathrm{C}($ rep G) & 30 & 0.0677 & 40.85 & - & - \\
\hline $\mathrm{C} \times \mathrm{I} \times \mathrm{G}$ & 9 & $0.3018 * * *$ & $190.32 * * *$ & - & - \\
\hline \multicolumn{6}{|l|}{ Nebraska } \\
\hline \multicolumn{6}{|l|}{2003} \\
\hline Rep & 3 & $27,165.12 * * *$ & $1,188.30 * * *$ & $5.71 * * *$ & 1.60 \\
\hline $\mathrm{C}$ & 29 & $8,199.05^{* * *}$ & $1,371.70 * * *$ & $1.94 * * *$ & $8.14 * * *$ \\
\hline $\mathrm{C} \times \operatorname{Rep}$ & 87 & $5,338.88 * * *$ & 80.23 & $0.48 * *$ & 0.83 \\
\hline I & 1 & $133,084.72 * * *$ & $3,059.61 * * *$ & $15.22 * * *$ & $71.53 * * *$ \\
\hline $\mathrm{I} \times \mathrm{C}$ & 29 & $1,469.07$ & 97.16 & 0.30 & 1.00 \\
\hline \multicolumn{6}{|l|}{2004} \\
\hline Rep & 5 & $20,190.22 * * *$ & $20,79.62 *$ & $0.82^{* *}$ & $12.21 * * *$ \\
\hline $\mathrm{C}$ & 22 & $10,125.16 * * *$ & $1,087.92 * *$ & $1.71 * * *$ & $4.47 * * *$ \\
\hline $\mathrm{C} \times \mathrm{Rep}$ & 114 & $2,064.11 *$ & 444.78 & $0.23 *$ & 0.85 \\
\hline I & 1 & $7,357.65^{*}$ & 498.05 & $0.83^{*}$ & 1.97 \\
\hline $\mathrm{I} \times \mathrm{C}$ & 22 & 987.91 & 308.36 & 0.19 & 0.27 \\
\hline
\end{tabular}

${ }^{a}$ Analysis of variance was analyzed using Proc GLM procedure in SAS (SAS Institute, Cary, NC). Values followed by $* * *$, and $* * *$ indicate significance at $P \leq 0.05, P \leq 0.01$, and $P<0.0001$, respectively.

${ }^{\mathrm{b}}$ Data on oil and protein content were not collected in Ohio. 
rectly used in the analysis) likewise were lower for July than for September. At the later rating date, there were several differences found from the July assessment. There was no clear agreement in the relative treatment effects of the cultivar for the two assessments. There was a significant effect of cultivar on the relative treatment effects of severity ratings in 2003 (Table 1 ), although most cultivars were not different from each other. Plots inoculated at growth stage R6 to R7 exhibited only mild chlorosis (data not shown). Inoculation significantly $(P<0.001)$ reduced plant height in plots inoculated at VC compared with the noninoculated control plots for both years (data not shown).

In Nebraska, where BPMV subgroup I was inoculated, there was not a significant interaction of cultivar and inoculation or cultivar alone $(P<0.05)$ on rugosity ratings based on the nonparametric marginal effects analysis (30) of the data in 2003 (Table 2). There was a significant increase in the relative treatment effects for chlorosis ratings among cultivars inoculated with BPMV in 2003 compared with not being inoculated (Table 2), with AgriPro 2903RR exhibiting the most chlorosis. However, in 2004, no significant differences in symptoms were found (data not shown). Rugosity ratings ranged from 1.0 to 1.2 for both inoculated and noninoculated plots, while chlorosis ratings ranged from 1.0 to 1.3 for noninoculated plots and from 1.0 to 1.7 for inoculated plots (data not shown).

Effect of BPMV infection on yield, seed composition, and seed quality. In Ohio, BPMV inoculation produced significant reductions in yield (Table 4). Subplots inoculated at VC had a 22 and $29 \%$ reduction in yield relative to noninoculated subplots, whereas plants inoculated at growth stage R6 to R7 showed a -0.5 and $5.5 \%$ reduction in yield in 2001 and 2003, respectively. (Table 4). In contrast, only Resnik and General (2003) showed significantly lower yield when inoculated at R6 to R7. Nonetheless, BPMV inoculation at the VC growth stage significantly reduced yield in both years across cultivars (Table 5). In Nebraska, there was not a significant cultivar-treatment interaction for yield in the analysis of variance for either year (Tables 3, 6, and 7). As in Ohio, BPMV inoculation significantly reduced yield in both years across cultivars by 11 and $3 \%$ in 2003 and 2004, respectively (Table 5).

BPMV inoculation affected seed composition for soybean cultivars evaluated in Nebraska in 2003, with differences between noninoculated and inoculated plots in protein and oil content. There was no significant cultivar-treatment interaction (Table 4). In 2004, there was no significant effect on percent protein content. However, there was significant decrease in oil content in seed from inoculated plots. For 2003 and 2004, there was an overall reduction of percent oil content by $0.5 \%$ in inoculated plots, with a proportional increase in protein content of $0.9 \%$ in the same plots (Table 6).

Seed coat mottling was observed in plots of inoculated and noninoculated soybean in all years and locations. In Ohio, the proportion of mottled seed was significantly higher for all entries except Tiffin and $\mathrm{HC} 95-24$ in subplots inoculated at VC in 2001 (Table 4). In subplots inoculated at R6 to R7, there was no significant increase in seed coat mottling among entries between noninoculated and inoculated; how-

Table 6. Mean treatment effects of noninoculated and inoculated at the VC and V3 to V4 growth stage with Bean pod mottle virus on soybean cultivars in Ohio and Nebraska, respectively

\begin{tabular}{|c|c|c|c|c|c|}
\hline $\begin{array}{l}\text { Location, } \\
\text { year }\end{array}$ & Treatment & Yield & $\begin{array}{c}\text { Mottled seed } \\
(\%)^{\mathrm{a}}\end{array}$ & $\begin{array}{l}\text { Oil content } \\
(\%)\end{array}$ & $\begin{array}{c}\text { Protein } \\
\text { content }(\%)\end{array}$ \\
\hline \multicolumn{6}{|l|}{ Ohio } \\
\hline \multirow[t]{3}{*}{2001} & Noninoculated & $1.9^{\mathrm{b}}$ & 36.0 & $\ldots$ & $\ldots$ \\
\hline & BPMV-inoculated & $1.5^{\mathrm{b}}$ & 65.7 & $\ldots$ & $\ldots$ \\
\hline & $P$ value & $<0.0001$ & $<0.0001$ & $\ldots$ & $\ldots$ \\
\hline \multirow[t]{3}{*}{2003} & Noninoculated & $2.1^{\mathrm{b}}$ & 7.0 & $\ldots$ & $\ldots$ \\
\hline & BPMV-inoculated & $1.5^{\mathrm{b}}$ & 18.4 & $\ldots$ & $\ldots$ \\
\hline & $P$ value & $<0.0001$ & $<0.0001$ & $\ldots$ & $\ldots$ \\
\hline \multicolumn{6}{|l|}{ Nebraska } \\
\hline \multirow[t]{3}{*}{2003} & Noninoculated & $429.1^{\mathrm{c}}$ & 66.6 & 25.1 & 48.0 \\
\hline & BPMV-inoculated & $376.6^{c}$ & 73.7 & 24.6 & 49.1 \\
\hline & $P$ value & $<0.0001$ & $<0.0001$ & $<0.0001$ & $<0.0001$ \\
\hline \multirow[t]{3}{*}{2004} & Noninoculated & $247.3^{c}$ & 35.2 & 20.9 & 37.8 \\
\hline & BPMV-inoculated & $237.3^{c}$ & 37.8 & 20.8 & 38.0 \\
\hline & $P$ value & 0.0244 & 0.2421 & 0.0237 & 0.0871 \\
\hline
\end{tabular}

a For percent mottling, a 100-seed subsample from each plot was counted for the number of seed exhibiting seed coat mottling, and this value was converted to percent mottled seed.

b Yield presented in $\mathrm{kg} / \mathrm{plot}$.

c Yield presented in $\mathrm{g} / \mathrm{plot}$.

Table 5. Yield and percent mottled seed for soybean cultivars evaluated in Ohio inoculated with Bean pod mottle virus (BPMV) at the unifoliate and R6 to R7 growth stages in the field in two-row plots ( 7.6 by $19 \mathrm{~m}$ ) during 2001 and $2003^{\mathrm{a}}$

\begin{tabular}{|c|c|c|c|c|c|c|c|c|c|c|c|c|c|c|c|c|}
\hline \multirow[b]{4}{*}{ Cultivar } & \multicolumn{8}{|c|}{2001} & \multicolumn{8}{|c|}{2003} \\
\hline & \multicolumn{4}{|c|}{ Yield (kg/plot) } & \multicolumn{4}{|c|}{ Mottled seed $(\%)^{b}$} & \multicolumn{4}{|c|}{ Yield (kg/plot) } & \multicolumn{4}{|c|}{ Mottled seed $(\%)^{b}$} \\
\hline & \multicolumn{2}{|c|}{ Unifoliate } & \multicolumn{2}{|c|}{ R6-R7 } & \multicolumn{2}{|c|}{ Unifoliate } & \multicolumn{2}{|c|}{ R6-R7 } & \multicolumn{2}{|c|}{ Unifoliate } & \multicolumn{2}{|c|}{ R6-R7 } & \multicolumn{2}{|c|}{ Unifoliate } & \multicolumn{2}{|c|}{ R6-R7 } \\
\hline & $\mathbf{I}$ & $\mathbf{N}$ & $\mathbf{I}$ & $\mathbf{N}$ & $\mathbf{I}$ & $\mathbf{N}$ & I & $\mathbf{N}$ & I & $\mathbf{N}$ & I & $\mathbf{N}$ & $\mathbf{I}$ & $\mathbf{N}$ & $\mathbf{I}$ & $\mathbf{N}$ \\
\hline Defiance & 1.6 & 1.9 & 1.9 & 1.8 & 38.8 & 20.0 & 22.5 & 27.5 & 1.0 & 1.4 & 1.4 & 1.5 & 11.5 & 1.0 & 0.5 & 0 \\
\hline Flint & 1.4 & 1.9 & 1.9 & 1.8 & 82.5 & 42.5 & 61.3 & 50.0 & & $\ldots$ & & & & & & \\
\hline General & 1.6 & 2.1 & 1.7 & 1.6 & 85.0 & 53.8 & 38.8 & 47.3 & 1.8 & 2.3 & 2.2 & 2.4 & 29.5 & 14.3 & 7.5 & 4.8 \\
\hline HF98-023 & 1.3 & 1.9 & 2.0 & 1.9 & 61.3 & 21.3 & 29.8 & 29.8 & 1.4 & 2.1 & 2.1 & 2.0 & 12.5 & 0.5 & 0 & 1.8 \\
\hline HS93-4118 & 1.5 & 1.9 & 1.7 & 1.7 & 93.8 & 37.5 & 48.8 & 46.3 & 1.5 & 2.3 & 2.0 & 2.1 & 33.8 & 25.0 & 7.8 & 8.8 \\
\hline Resnik & 1.6 & 1.9 & 2.2 & 1.8 & 55.0 & 30.0 & 30.0 & 33.8 & 1.6 & 2.2 & 2.0 & 2.3 & 34.8 & 9.8 & 4.8 & 7.3 \\
\hline Tiffin & 1.6 & 1.8 & 2.0 & 2.1 & 52.5 & 48.8 & 23.3 & 28.8 & 1.4 & 1.9 & 1.9 & 2.0 & 29.0 & 10.0 & 4.0 & 1.5 \\
\hline Stalwart & 1.6 & 2.0 & 2.2 & 2.3 & 57.5 & 40.0 & 19.8 & 23.3 & 1.6 & 2.1 & 1.9 & 2.0 & 16.3 & 0 & 0.8 & 0 \\
\hline HC95-15 & 1.5 & 2.0 & 1.9 & 1.8 & 75.0 & 36.3 & 12.5 & 13.8 & 1.5 & 2.1 & 1.9 & 2.0 & 8.0 & 0.5 & 2.8 & 0.3 \\
\hline HC95-24 & 1.3 & 1.8 & 1.7 & 1.7 & 40.0 & 28.8 & 15.0 & 20.3 & 1.5 & 2.3 & 1.9 & 2.0 & 6.3 & 0.3 & 0 & 0 \\
\hline Williams82 & 1.4 & 1.8 & 1.8 & 1.8 & 82.5 & 37.5 & 47.5 & 40.0 & $\mathrm{Nt}$ & $\mathrm{Nt}$ & $\mathrm{Nt}$ & $\mathrm{Nt}$ & 2.8 & 9.0 & 7.8 & 8.3 \\
\hline Mean & 1.7 & $\ldots$ & 1.9 & $\ldots$ & 50.9 & $\ldots$ & 32.3 & $\ldots$ & 1.8 & $\ldots$ & 2.0 & $\ldots$ & 7.9 & $\ldots$ & 3.2 & $\ldots$ \\
\hline Two-way LSD ${ }^{c}$ & 0.2 & $\ldots$ & 0.2 & $\ldots$ & 14.2 & $\ldots$ & 12.4 & $\ldots$ & 0.3 & $\ldots$ & 0.2 & $\ldots$ & 13.4 & $\ldots$ & NS & $\ldots$ \\
\hline Three-way LSD & 0.2 & $\ldots$ & $\ldots$ & $\ldots$ & 13.3 & $\ldots$ & $\ldots$ & $\ldots$ & $\ldots$ & $\ldots$ & 0.25 & $\ldots$ & 13.4 & $\ldots$ & $\ldots$ & $\ldots$ \\
\hline
\end{tabular}

a I = BPMV-inoculated subplots, $\mathrm{N}=$ noninoculated subplots, and $\mathrm{Nt}=$ not taken, due to very poor and uneven stands.

${ }^{\mathrm{b}}$ For percent mottling, a 100-seed subsample from each plot was counted for the number of seed exhibiting seed coat mottling, and this value was converted to percent mottled seed.

${ }^{\mathrm{c}}$ Treatments were compared using Fisher's protected least significant difference (LSD; $P \leq 0.05 ; \alpha=0.05$ ); two-way interaction between inoculated and noninoculated and three-way interaction among cultivar-inoculation-growth stage; NS $=$ not significant. 
ever, BPMV inoculation caused a significant increase in the percentage of seed mottling across entries (Table 5). In Nebraska, there was a significant increase in mottled seed in the inoculated plots compared with the noninoculated plots in 2003 (Tables 3 and 7). In 2004, there were more mottled seed in the inoculated plots compared with noninoculated plots, but these differences were not significant (Table 7). In 2003, there were significant differences $(P<0.05)$ in seed quality with noninoculated plots having a better overall seed quality rating (data not shown).

The biserial correlations (Table 8) indicated that the presence of BPMV had an effect on yield and other agronomic properties of soybean in three out of the four studies. In Ohio during 2001 and 2003, yield and percent mottled seed were significantly $(P<0.001)$ lower in plants with BPMV than without. However, in 1 year in Nebraska (2003), yield was actually higher $(P<0.001)$ when BPMV was present than when BPMV was absent in the biserial correlation; in the other year in Nebraska (2004), there was no significant effect.

\section{DISCUSSION}

Yields of soybean inoculated at the VC (Ohio) and V3 (Nebraska) growth stage with BPMV were significantly lower than noninoculated plots. Although there was a range in yield reduction among evaluated soybean cultivars and years, the overall reduction was $16.3 \%$ across locations and years. These yield reductions observed in this study were not as high as previously reported $(6,14)$. Although the noninoculated plots were symptom free, BPMV was identified in the noninoculated controls in both years and locations; thus, this may be a contributing factor. However, it is probable that variability in yield among the large number of cultivars used in this study masked reductions in yield that can be detected with a single or few cultivars. It also is possible that breeding programs have improved tolerance to BPMV since those earlier studies. Breeding programs do not typically make selections for BPMV; however, by culling out poorquality seed and lower-yielding lines, BPVM tolerance could have been selected in years with high BPMV incidence. Differences in seed coat mottling were correlated to BPMV infection in this study. Krell et al. (16) found that virus antigen levels in seed were not correlated to the amount of seed coat mottling; therefore, they suggested not using seed coat mottling as an indicator of soybean cultivar sensitivity to BPMV infection. Other results indicate that the level of seed coat mottling is strongly influenced by genotype and other environmental stresses, especially temperature $(2,12,32,34,35)$. Thus, although seed coat mottling is strongly associated with BPMV infection, it is important to account for other variables that affect seed coat mottling development when assessing soybean cultivars for tolerance or resistance to BPMV.

The data from Nebraska demonstrate that BPMV infection affects seed oil and protein composition. In current markets, high oil and protein content are desired for international trade of soybean products.

Table 8. Biserial correlations between presence of Bean pod mottle virus (BPMV) on soybean yield, percent mottled seed, percent oil content, and percent protein content in plots inoculated and noninoculated with BPMV ${ }^{\mathrm{a}}$

\begin{tabular}{llccc}
\hline Location, year & Yield & $\begin{array}{c}\text { Percent mottled } \\
\text { seed }^{\mathbf{b}}\end{array}$ & $\begin{array}{c}\text { Percent oil } \\
\text { content }\end{array}$ & $\begin{array}{c}\text { Percent protein } \\
\text { content }\end{array}$ \\
\hline Ohio & & & & \\
2001 & $-0.213^{* * *}$ & $0.188^{* * *}$ & $\ldots$ & $\ldots$ \\
2003 & $-0.368^{* * *}$ & $0.349^{* * *}$ & $\ldots$ & $\ldots$ \\
Nebraska & & & & \\
2003 & $0.142^{* * *}$ & $0.048^{* *}$ & $0.092^{* * *}$ & $0.0226^{*}$ \\
2004 & 0.008 & 0.004 & 0.009 & 0.006 \\
\hline
\end{tabular}

a Correlations between both the percent seed coat mottling and yield with the presence or absence of BPMV in the plots was calculated using a point-serial correlation coefficient as described by Gibbons (7). Values followed by $* * *$, and $* * *$ indicate significant differences at $P \leq 0.05,0.01$, and 0.001 , respectively.

${ }^{b}$ For percent mottling, a 100-seed subsample from each plot was counted for the number of seed exhibiting seed coat mottling, and this value was converted to percent mottled seed.

Table 7. Effects of inoculation with Bean pod mottle virus (BPMV) at growth stage V3 to V4 on yield, percent mottled seed, percent oil content, and percent protein content of soybean cultivars evaluated in Nebraska in 2004 ${ }^{\mathrm{a}}$

\begin{tabular}{|c|c|c|c|c|c|c|c|c|c|c|c|c|}
\hline \multirow[b]{2}{*}{ Cultivar } & \multicolumn{3}{|c|}{ Yield (g/plot) } & \multicolumn{3}{|c|}{ Mottled seed $(\%)^{b}$} & \multicolumn{3}{|c|}{ Oil content (\%) } & \multicolumn{3}{|c|}{ Protein content (\%) } \\
\hline & I & $\mathbf{N}$ & Mean & I & $\mathbf{N}$ & Mean & I & $\mathbf{N}$ & Mean & $\mathbf{I}$ & $\mathbf{N}$ & Mean \\
\hline Stine S3632-4 & 228.4 & 228.1 & 228.3 & 37.1 & 29.0 & 33.1 & 20.4 & 20.7 & 20.6 & 38.2 & 38.0 & 38.1 \\
\hline Stine S3181-4 & 195.6 & 186.0 & 190.8 & 50.5 & 38.6 & 44.6 & 20.8 & 20.6 & 20.7 & 37.7 & 37.3 & 37.5 \\
\hline NK/Syngenta S32-G5 & 240.5 & 274.4 & 257.5 & 21.0 & 36.6 & 28.8 & 20.4 & 20.4 & 20.4 & 38.0 & 38.0 & 38.0 \\
\hline NK/Syngenta S327R & 244.0 & 230.6 & 237.3 & 45.8 & 47.7 & 46.8 & 20.8 & 21.2 & 21.0 & 38.1 & 37.7 & 37.9 \\
\hline Mycogen 5B288RR & 274.9 & 265.6 & 270.3 & 40.2 & 32.8 & 36.5 & 21.0 & 21.0 & 21.0 & 37.6 & 37.6 & 37.6 \\
\hline Mycogen 5B311RR & 174.4 & 209.4 & 191.9 & 33.2 & 46.8 & 40.0 & 20.5 & 20.5 & 20.5 & 37.7 & 37.6 & 37.7 \\
\hline Mycogen 5B242RR & 241.3 & 249.0 & 245.2 & 41.0 & 38.0 & 39.5 & 21.6 & 21.5 & 21.6 & 37.4 & 37.8 & 37.6 \\
\hline Latham E2857R & 259.8 & 251.8 & 255.8 & 44.3 & 31.0 & 37.7 & 21.2 & 21.1 & 21.2 & 38.6 & 38.5 & 38.6 \\
\hline Latham E2900R & 262.5 & 278.8 & 270.7 & 44.3 & 35.2 & 39.8 & 21.7 & 21.2 & 21.5 & 38.2 & 37.6 & 37.9 \\
\hline LG Seeds C2991RR & 229.8 & 250.9 & 240.4 & 44.7 & 43.8 & 44.3 & 21.4 & 21.6 & 21.5 & 38.8 & 38.6 & 38.7 \\
\hline LG Seeds C3031RR & 258.9 & 285.9 & 272.4 & 50.2 & 39.4 & 44.8 & 20.7 & 20.8 & 20.8 & 37.8 & 37.7 & 37.8 \\
\hline LG Seeds C3110NR & 282.8 & 277.0 & 279.9 & 28.8 & 24.6 & 26.7 & 21.4 & 21.1 & 21.3 & 39.4 & 39.1 & 39.3 \\
\hline Kaup 299R & 200.2 & 210.4 & 205.3 & 40.0 & 32.2 & 36.1 & 21.4 & 21.7 & 21.6 & 37.4 & 37.8 & 37.6 \\
\hline Kaup 279R & 265.7 & 274.0 & 269.9 & 48.4 & 56.0 & 52.2 & 20.9 & 21.5 & 21.2 & 38.5 & 38.1 & 38.3 \\
\hline Kaup 2748R & 250.4 & 264.8 & 257.6 & 36.5 & 40.5 & 38.5 & 21.2 & 21.2 & 21.2 & 36.5 & 36.7 & 36.6 \\
\hline Croplan RT3176 & 182.5 & 202.7 & 192.6 & 31.7 & 23.4 & 27.6 & 20.8 & 20.5 & 20.7 & 37.9 & 37.7 & 37.8 \\
\hline Croplan RT3253 & 264.2 & 265.2 & 264.7 & 25.2 & 36.2 & 30.7 & 20.8 & 20.9 & 20.9 & 37.6 & 37.6 & 37.6 \\
\hline Croplan RT3422 & 246.0 & 248.4 & 247.2 & 56.5 & 47.0 & 51.8 & 20.5 & 20.5 & 20.5 & 38.8 & 38.6 & 38.7 \\
\hline Asgrow 3005 & 240.6 & 278.0 & 259.3 & 34.2 & 18.1 & 26.2 & 21.0 & 21.0 & 21.0 & 37.7 & 37.7 & 37.7 \\
\hline Asgrow 3002 & 218.8 & 226.1 & 222.5 & 35.4 & 51.5 & 43.5 & 20.6 & 20.8 & 20.7 & 38.5 & 38.1 & 38.3 \\
\hline Dekalb DKB31-52 & 251.6 & 284.0 & 267.8 & 15.0 & 9.7 & 12.4 & 21.0 & 21.1 & 21.1 & 37.4 & 36.8 & 37.1 \\
\hline Midwest Seed Genetics GR2101 & 237.4 & 274.2 & 255.8 & 26.8 & 22.7 & 24.8 & 20.0 & 20.1 & 20.1 & 38.7 & 38.2 & 38.5 \\
\hline Midwest Seed Genetics GR2747 & 219.6 & 195.2 & 207.4 & 44.2 & 26.5 & 35.4 & 20.9 & 21.4 & 21.2 & 37.3 & 37.2 & 37.3 \\
\hline Cultivar LSD $(\alpha=0.05)^{\mathrm{c}}$ & 50.1 & 45.8 & 24 & 24.8 & 22.6 & 11.8 & 0.5 & 0.5 & 0.3 & 1.0 & 1.0 & 0.5 \\
\hline
\end{tabular}

a I = BPMV-inoculated subplots and $\mathrm{N}=$ noninoculated subplots.

${ }^{\mathrm{b}}$ For percent mottling, a 100-seed subsample from each plot was counted for the number of seed exhibiting seed coat mottling, and this value was converted to percent mottled seed.

${ }^{\mathrm{c}} \mathrm{LSD}=$ least significant difference. 
For example, premiums are paid in Asian markets for soybean seed that contain a minimum of $19 \%$ oil and $35 \%$ protein. Here, the BPMV infection on soybean processing is twofold and could either increase or decrease profits. For example, the $0.5 \%$ reduction in oil content induced by BPMV could negate price premiums for producers. On the other hand, the protein increase associated with BPMV infection $(0.9 \%)$ could increase soybean protein content to the optimal level of $35 \%$ or higher and increase profits. Nonetheless, the overall decrease in yield associated with BPMV infection may negate any increase due to high protein content. The overall impact of BPMV on soybean cultivars that are being marketed as Processor Preferred (high oil and protein content) is unknown at this time.

BPMV was detected in the noninoculated plots at both locations despite efforts to control virus vectors. Sampling to evaluate infection within subplots was done later in the season and appears to be associated with the unsuccessful control of leaf-feeding insects in the field plots. For the studies performed in Ohio, there was evidence of some feeding by Mexican bean beetles (Epilachna varivestis Mulsant). In Nebraska, BLB, banded cucumber beetles (Diabrotica balteata LeConte), spotted cucumber beetles (D. undecimpunctata howardi Barber), and western corn rootworm beetles (D. virgifera virgifera LeConte), all vectors of BPMV, were identified $(6,20)$. Despite the inability to maintain noninoculated plots at $0 \% \mathrm{BPMV}$ incidence, there were significant differences observed between inoculated and noninoculated plots.

In Ohio, BPMV inoculation at the VC growth stage resulted in a $25.5 \%$ yield reduction. A smaller reduction (2.5\%) was found in plants inoculated at R6 to R7. These results are comparable with those of Hopkins and Mueller (10), who demonstrated that inoculation of cvs. Bragg and Lee 74 at growth stage V1 caused a 44.3 and $13.7 \%$ yield reduction, respectively. Interestingly, an intermediate reduction in yield $(7 \%)$ was found for plants inoculated at growth stage V3 to V4 in Nebraska despite the difference in location and BPMV strain type. The work by Windham and Ross (37) demonstrated that inoculation of cvs. Centennial and Ransom must occur prior to growth stage V6 for significant reductions in yield. The greater effect of early virus inoculation on yield reduction is critical for developing management strategies for producers.

The agronomic effects of inoculation prior to the V6 growth stage also may play a role in interpretation of survey results. In Nebraska, a survey conducted in 2001 and 2002 showed that BPMV infection was present in 54 and $91 \%$ of the fields tested and that the within-field incidence ranged from 0 to $90 \%$ and 0 to $100 \%$ in 2001 and
2002, respectively (9). However, the plant tissue was collected in late July and August at growth stage R2 to R5, significantly beyond the V6 growth stage. Future surveys to determine the incidence of BPMV at soybean vegetative stages coupled with BLB population assessments would provide information for management programs associated with early control of BLB populations and provide a better assessment of potential impact on production.

Current management strategies to reduce the impact of BPMV for soybean producers include the use of insecticide seed treatments (42) and foliar insecticide applications (15). The use of soybean cultivars resistant or tolerant to BPMV infection would be the most practical approach for producers to manage this problem; however, genetic material tolerant to BPMV is not currently commercially available. However, the range of response observed among the soybean cultivars used in this study suggests that tolerance to BPMV may exist in soybean germplasm. Another possibility for BPMV management might be the use of soybean cultivars that are resistant to insect feeding (11). By preventing feeding by vectors like BLBs, the spread and incidence of BPMV could be reduced

\section{ACKNOWLEDGMENTS}

Funding for these studies was received in part from the Nebraska Soybean Board, North Central Soybean Research Program, Ohio Seed Improvement Association, Ohio Soybean Council, and the Ohio Agricultural Research and Development Center Research Enhancement Competitive Grants Program. Salaries and research support were provided by State and Federal funds appropriated to the University of Nebraska and The Ohio Agricultural Research and Development Center, The Ohio State University. The Nebraska authors wish to thank the following seed companies: AgriPro, Asgrow, Croplan Genetics, Garst, Kaup, Latham, LG Seeds, Midwest Genetics, Mycogen, Stine, and Syngenta for providing the soybean seed for this study; E. Colfax, K. Gillispie, M. Stamm, S. Watson, T. Weissling, and S. Werner for assistance with virus inoculations; and $\mathrm{L}$. Corte and D. White for field preparation, planting, and harvesting. The Ohio authors wish to thank R. Anderson for assistance with virus purification; J. Abt, J. Barnes, M. Jones, H. Jia, K. Bluemel, and M. Vega-Sanchez for assistance with virus inoculations; D. Carpio and E. Helliwell for assistance with ELISAs; D. Carpio for assistance with subtype characterization; and B. Bardall and R. Berry for field preparation, planting, and harvesting.

\section{LITERATURE CITED}

1. Brunner, E., and Prui, M. 2001. Nonparametric methods in factorial designs. Stat. Pap. 42:152.

2. Cooper, R. L. 1966. A major gene for resistance to seed coat mottling in soybeans. Crop Sci. 6:290-292.

3. Di, R., Purcell, V., Collins, G. B., and Ghabrial, S. A. 1996. Production of transgenic soybean lines expressing the bean pod mottle virus coat protein precursor gene. Plant Cell Rep. 15:746-750.

4. Dorrance, A. E., Gordon, D. T., Schmitthenner, A. F., and Grau, C. R. 2001. First report of Bean pod mottle virus in soybean in Ohio. Plant Dis. 85:1029.
5. Doughty, D. M., Lee, M. E., Kurtzweil, N. C., Boerboom, C. M., and Grau, C. R. 2001. Occurrence of soybean viruses and association with green stem of soybean in Wisconsin. (Abstr.) Phytopathology 91:S176.

6. Gergerich, R. C. 1999. Comoviruses: Bean pod mottle comovirus. Pages 61-61 in: Compendium of Soybean Diseases, 4th ed. G. L. Hartman, J. B. Sinclair, and J. C. Rupe, eds. American Phytopathological Society, St. Paul, $\mathrm{MN}$.

7. Gibbons, J. D. 1976. Nonparametric Methods for Quantitative Analysis. Holt, Rinehart and Winston, New York.

8. Giesler, L. J., Ghabrial, S. A., Hunt, T. E., and Hill, J. H. 2002. Bean pod mottle virus: A threat to U.S. soybean production. Plant Dis. 86:1280-1289.

9. Giesler, L. J., and Ziems, A. D. 2006. Incidence of Alfalfa mosaic virus, Bean pod mottle virus and Soybean mosaic virus in Nebraska soybean fields. Plant Health Progress doi:10.1094/PHP-2006-0424-01-HM.

10. Gu, H., Clark, A. J., de Sa, P. B., Pfeiffer, T. W., and Ghabrial, S. A. 2002. Genetic diversity among isolates of Bean pod mottle virus. Phytopathology 92:446-452.

11. Hammond, R. B., Bierman, P., Levine, E. and Cooper, R. L. 2001. Field resistance of two soybean germplasm lines, HC95-15MB and HC95-24MB, against bean leaf beetle (Coleoptera: Chrysomelidae), western corn rootworm (Coleoptera: Chrysomelidae), and Japanese beetles (Coleoptera: Scarabaidae). J. Econ. Entomol. 94 (6):1594-1601.

12. Hobbs, H. A., Hartman, G. L., Wang, Y., Hill, C. B., Bernard, R. L., and Pedersen, W. L. 2003. Occurrence of seed coat mottling in soybean plants inoculated with Bean pod mottle virus and Soybean mosaic virus. Plant Dis. 87:1333-1336.

13. Hobbs, H. A., Hill, C. B., Grau, C. R., Koval, N. C., Wang, Y., Pedersen, W. L., Domier, L. L, and Hartman, G. L. 2006. Green stem disorder of soybean. Plant Dis. 90:513-518.

14. Hopkins, J. D., and Mueller, A. J. 1984. Effect of bean pod mottle virus on soybean yield. J. Econ. Entomol. 77:943-947.

15. Krell, R. K., Pedigo, L. P., Hill, J. H., and Rice, M. E. 2004. Bean leaf beetle (Coleoptera: Chrysomelidae) management for reduction of Bean pod mottle virus. J. Econ. Entomol. 97:192-202.

16. Krell, R. K., Pedigo, L. P., Rice, M. E., Westgate, M. E., and Hill, J. H. 2005. Using planting date to mange Bean pod mottle virus in soybean. Crop Prot. 24:909-914.

17. Langham, M. A., Doxtader, D. C., Smolik, J. D., and Scott, R. A. 1999. Outbreak of a viral disease affecting soybeans [Glycine max (L.) Merrill] in South Dakota. (Abstr.) Phytopathology 89:S43.

18. Lin, M. T., and Hill, J. H. 1983. Bean pod mottle virus: occurrence in Nebraska and seed transmission in soybeans. Plant Dis. 67:230233.

19. Louie, R., Redinbaugh, M. G., Gordon, D. T., Abt, J. J., and Anderson, R. J. 2000. Maize necrotic streak virus, a new maize virus with similarity to species of the family Tombusviridae. Plant Dis. 84:1133-1139.

20. Mabry, T. R., Hobbs, H. A., Steinlage, T. A., Johnson, B. B., Pedersen, W. L., Spencer, J. L., Levine, E., Isard, S. A., Domier, L. L., and Hartman, G. L. 2003. Distribution of leaffeeding beetles and Bean pod mottle virus (BPMV) in Illinois and transmission of BPMV in soybean. Plant Dis. 87:1221-1225.

21. Milbrath, G. M., McLaughlin, M. R., and Goodman, R. M. 1975. Identification of bean pod mottle virus from naturally infected soybeans in Illinois. Plant Dis. Rep. 59:982-983.

22. Pitre, H. N., Patel, V. C., and Keeling, B. L. 1979. Distribution of bean pod mottle disease 
of soybean in Mississippi. Plant Dis. Rep. 63:419-423.

23. Quiniones, S. S., Dunleavy, J. M., and Fisher, J. W. 1971. Performance of three soybean varieties inoculated with soybean mosaic virus and bean pod mottle virus. Crop Sci. 11:662

24. Reddy, M. S. S., Ghabrial, S. A., Redmond, C. T., Dinkins, R. D., and Collins, G. B. 2001. Resistance to Bean pod mottle virus in transgenic soybean lines expressing the capsid polyprotein. Phytopathology 91:831-838.

25. Redinbaugh, M. G., Vacha, J., Berry, S. A., and Dorrance, A. E. 2003. Comparison of early and late inoculations of soybean with Bean pod mottle virus. (Abstr.) Phytopathology 93:S73.

26. Ross, J. P. 1963. Interaction of the soybean mosaic and bean pod mottle viruses infecting soybeans. (Abstr.) Phytopathology 53:887.

27. Ross, J. P. 1968. Effect of single and double infection of soybean mosaic and bean pod mottle viruses on soybean yield and seed characters. Plant Dis. Rep. 52:344-348.

28. Ross, J. P., and Butler, A. K. 1985. Distribution of bean pod mottle virus in soybeans in North Carolina. Plant Dis. 69:101-103.
29. Schwenk, F. W., and Nickell, C. D. 1980. Soybean green stem caused by bean pod mottle virus. Plant Dis. 62:863-865.

30. Shah, D. A, and Madden, L. V. 2004. Nonparametric analysis of ordinal data in designed factorial experiments. Phytopathology 94:3343.

31. Skotland, C. B. 1958. Bean pod mottle virus of soybeans. Plant Dis. Rep. 42:1155-1156.

32. Srinivasan, A., and Arihara, J. 1994. Soybean seed discoloration and cracking in response to low temperatures during early reproductive growth. Crop Sci. 34:1611-1617.

33. Sutula, C. L., Gillet, J. M., Morrissey, S. M., and Ramsdell, D. C. 1986. Interpreting ELISA data and establishing the positive-negative threshold. Plant Dis. 70:722-726.

34. Takahashi, R., and Abe, J. 1994. Genetic and linkage analysis of low temperature-induced browning in soybean seed coats. J. Hered. 85:447-450.

35. Takahashi, R., and Asanuma, S. 1996. Association of $T$ genes with chilling tolerance in soybeans. Crop Sci. 36:559-562.

36. Walters, H. J. 1958. A virus disease complex in soybeans in Arkansas (Abstr.). Phytopathology 48:346.

37. Windham, M. T., and Ross, J. P. 1985. Phenotypic responses of six soybean cultivars to bean pod mottle virus infection. Phytopathology 75:305-309.

38. Zaumeyer, W. J., and Thomas H. R. 1948. Pod mottle, a virus disease of beans. J. Agric. Res. 77:81-96.

39. Zheng, C., Chen, P., Hymowitz, T., Wickizer, S., and Gergerich, R. 2005. Evaluation of Gly cine species for resistance to Bean pod mottle virus. Crop Prot. 24:46-56.

40. Ziems, A. D., Giesler, L. J., and Graef, G. L. 2005. Commercial soybean variety response to Bean pod mottle virus infection. (Abstr.) Phytopathology 95:S118.

41. Ziems, A. D., Giesler, L. J. Graef, G. L., and Lane, L. C. 2001. Effect of Bean pod mottle virus on soybean seed quality. (Abstr.) Phytopathology 91:S100.

42. Ziems, A. D., Giesler, L. J., and Hunt, T. E. 2002. Entomological Society of America Annual Meeting. Fort Lauderdale, FL. Entomological Society of America, Lanham, MD. 